XV.

\title{
THE RUMMINDEI INSCRIPTION AND THE CONVERSION OF ASOKA TO BUDDHISM.
}

By J. F. FLEET, I.C.S. (Reto.), Ph.D., C.I.E.

\section{The Rummindēi inscription.}

THE text of the Rummindēi inscription, styled at first " the Aśoka edict of Padariā," appears to have been first published by Professor Buihler, in the Anzeiger for the 7th January, 1897, of the Philosophical and Historical Section of the Imperial Academy of Sciences, Vienna. A translation of it was given by M. Barth in the Journal des Savants, 1897. 73. The record was fully edited by Professor Buhler, with an excellent facsimile, in the Epigraphia Indica, 5. 1 ff. Some difficult terms in it have been examined by Professor Pischel in the Sitzungsberichte of the Royal Prussian Academy of Sciences, 1903. 724 ff. And Mr. Vincent Smith has favoured us with one translation of it in his Asoka, 145, and another in an article entitled "The Rummindēi Inscription, hitherto known as the Paḍariyā Inscription, of Asōka," published in the Indian Antiquary, 1905. 1 ff. From this last article we learn that the broken pillar which bears the inscription stands close to a mound of ruins, near the top of which there is a shrine of a goddess known as Rummindēi ; that this mound is close on the north of another mound which marks the site of an ancient village or small town; that the tapp $\bar{a}$ itself, the subdivision, including a number of villages, also is known by the name Rummindēì ; and that, consequently, the record is to be Downloaded from https://www.cambridge.org/core. INSEAD, on 22 May 2018 at 07:46:26, subject to the Cambridge Core terms of use, available at https://www.cambridge.org/core/terms. 
known as the Rummindēi inscription, better than as the Padariya inscription from the name of the nearest inhabited village, about a mile to the south. In connexion with the statement that Rummindēi is also the name of the tapp $\bar{a}$, I may observe that the Suttanipāta, verse 683, tells us that Buddha was born :- Sakyāna gāmē janapadē Lumbineyyē; "in a village of the Sakyas in the Lumbin country, territory, or district." I may add that the record cannot be properly classed as an "edict" of Asóka, inasmuch as it does not commence with any of the formulae presented in the edicts, and that there is not, in fact, anything to mark it as a record framed by the king at all: it appears to have been drawn up by the local authorities, and incised by them on the pillar set up by Assōka.

The special interest which attaches to this record lies in the fact, which was recognized as soon as the record was discovered, that, as there is no reason for supposing that the pillar does not stand in the very place in which it was originally set up, the record locates the exact traditional site of the place where Buddha was born,- the Lumbini or Lumbinivana grove or garden of the Divyāvadana and the Lalitavistara, and the Lumbinivana, v.l. Lumbinivana, of the Nidānakathā. The name of the village as given in the record, Lummini, is the Prākrit form of the Sanskrit Lumbinĭ : and, the change of $l$ to $r$ being a very common one, we recognize at once that the first component of the modern name Rummindēi is the ancient Lumbiñ̆, Lummini. ${ }^{1}$

The text of the inscription, which I give from the facsimile accompanying Professor Bühler's article, runs as follows :-

I The name Rummindēĩ appears to be not unique. Babu P. C. Mukherji's sketch-map, Antiquities in the Tarai, plate 1, shews a village 'Rumin-dei' about twenty-four miles towards the west-by-south from the place where the inscribed pillar is. It may give an indication of the stretch of the ancient Lumbini district. 


\section{Text.}

1 Dēvānapiyēna Piyadasina lājina vissati-vass-ābhisitēna

2 atana āgācha mahīyite hida Budhe jāte Sakya-mun=iti

3 sil-āvi-gaḍa-bhīchā kāläpita silā-thabhe cha usapāpite

4. hida Bhagavam jātē=ti Lummini-gāme ubalike kațe

5 ațhabhāgiye cha

The text is clear and unmistakable throughout. And my reading is exactly the same as that laid down by previous writers; except that in line $3 \mathrm{I}$ take $c h \bar{\alpha}$, not as another form of cha, 'and,' but as forming with the preceding syllable the word $b h \bar{\imath} c h \bar{\alpha}$. There are, however, certain expressions in the record, regarding the interpretation of which I differ.

The first term that calls for notice is mahiyite, line 2. This is equivalent to the Sanskrit mahivyitam, the nominative singular neuter of the past participle passive of the nominal verb mahìy, 'to be joyous or happy; to prosper, thrive ; to be held in high honour.'

This word has been taken here as meaning 'homage was done,' 'worship was done,' ' reverence was done.' And, without doubt, instances might be cited in which mahizy, which is explained by grammarians and commentators as being used $p \bar{u} j \bar{\alpha} y \bar{\alpha} m$, 'in the sense of $p \bar{u} j \bar{\alpha}$,' and vriddhau, 'in the sense of growth, increase, etc.,' has a meaning which is fully equivalent to that of 'to be worshipped as a religious object.' But ' to do $p \bar{u} j \bar{a}$ ' does not necessarily mean ' to do religious worship :' it denotes also the act of paying respect to great, influential, or venerable people. And, whereas mahỹy is ultimately connected with the root from which we have also mahat, ' great,' there are numerous passages in which, we can see, it plainly means ' to be made great, to be honoured.' Downloaded from https://www.cambridge.org/core. INSEAD, on 22 May 2018 at 07:46:26, subject to the Cambridge Core terms of use, available at https://www.cambridge.org/core/terms. 
Thus:-

Mānavadharmaśāstra, 4. 260:- Vyapēta-kalmashō nityam Brahma-lōkē mahiyatē; "(a Brāhman, conducting himself in this manner, and becoming acquainted with the Vëdas), becomes freed from sin, and is ever glorified in the world of Brahman."

Ibid., 5. 155 :-- Patim śuśrūshatē yēna tēna svargē mahiyate ; "if (a woman) obeys her husband, by that she is exalted in heaven."

Ibid., 8. 313:- Yat=kshiptō marshayaty =ārtais = tēna svargē mahiyatē; " if (a king), when he is reviled by those in distress, bears it with patience, he is on that account magnified in heaven."

In rendering the word in the above three passages by "is glorified, exalted, magnified," I have simply followed Dr. Burnell, The Ordinances of Manu, endorsed by Professor Buihler, The Laws of Manu (SBE, vol. 25); the latter using 'exalted' in the three cases. But it is obvious that the idea of being 'worshipped' is inadmissible here.

Again, we have in the Mahābhārata (Calcutta ed.), 3. $§ 83,6027$ :- Sarva-vyādhi-vinirmuktō Brahma-lōkē mahiyatē; " $\mathrm{O}$ best of the Bharatas!, a man who bathes at the tīrtha of Kāsíśvara) becomes freed from all ailments and is exalted in the world of Brahman."

So, also, we have in the Rāmāyana (Bombay ed.), 1. $§ 1$, 99 :- Sa-putra-pautrah sa-gaṇaḥ prētya svargē mahìyatē; "(the man who reads this tale, the Rāmäyana, which confers long life),- when he dies, he is exalted in heaven along with his sons, his sons' sons, and his followers."

Ibid. (Gorresio), 2. § 12, 37 :- Vivesśa Rāmasya mahātmanō griham mahīyamānam; "(Sumantra) entered the honoured house of the high-minded Rāma."

And in the Bhațtikävya, 2. 38, Viśvämitra says to Rāma :- Mahīyyamānā bhavat=ātimātram . . . . . bhümiḥ; "honoured beyond all measure by thee (who didst overcome the voracious demons at the sacrifice of Downloaded from https://www.cambridge.org/core. INSEAD, on 22 May 2018 at 07:46:26, subject to the Cambridge Core terms of use, available at https://www.cambridge.org/core/terms. 
the gods), the earth, (thus possessed of a hero, is not ashamed even before the heavens adorned by Indra)."

It is thus plain that mahryite may mean in the Rummindēi inscription 'it was honoured, honour was done,' quite as much as 'it was worshipped, worship was done." But Aśoka cannot have done "worship" at the Lumbinivana unless he was a Buddhist. And, whatever may be the apparent purport and bearing of certain statements in the Dipavamsa and the Mahãvamsa, his records make it certain that he had not become a Buddhist when he visited the village Lummini,- - in the twenty-first year after his anointment to the sovereignty : they make it clear (see page $496 \mathrm{f}$. below) that it was only about the middle of the thirtieth year that he was converted to Buddhism, and became a Buddhist disciple or lay-worshipper.

In these circumstances, I take mahĭyite as meaning here, not 'worship was done,' but 'honour was done.' And I take the whole phrase :- lājina . . . . . atana àgācha mahiyite, - literally " by the king, by himself, having come, honour was done," - as meaning "the king did (this place) the honour of coming (here) in person." Aśoka was on a state progress through part of the northern districts of his dominions: he was making a dhammayatata, a tour in connexion with his duties as a king, in accordance with a practice which, as he plainly tells us in his eighth rock-edict (see more fully page 490 below), he had laid down for himself: ${ }^{1}$ He was encamped somewhere near the village Lummini. And, attracted by what was told him in connexion with a site at that place,

1 Quite possibly, of course, it was this identical tour that provided the basis for the story in the Divyāvadāna, ed. Cowell and Neil, $389 \mathrm{ff}$, of how Aśoka went round, under the guidance of the Sthavira Upagupta, to the various places at which Buddha had resided, commencing with the Lumbinivana, "in order to honour them and to mark them out for the benefit of future generations.' 
he paid that site a visit, and, naturally enough in the cose of so liberal-minded a monarch, ${ }^{1}$ conferred favours on its possessors in recognition of the interesting event which had occurred there, and made arrangements that the site should be marked out and protected. It was doubtless on the same occasion that, as is recorded in the Nigliva inscription (EI, 5. 5), he visited the Stūpa of Konākaimana, on which he had previously conferred the favour either of causing it to be restored so as to make it twice as large as it had become, or of doubling an endowment which was attached to it.

The next expression calling for notice is one which we have in line 3,- silävigadabhīch $\bar{\alpha}$.

Previous examiners of this record have taken the cha as a variant, met with in the edicts, of $c h a$, 'and.' Before it, they have found the compound silā-vigadabh $\bar{\imath}$. And this they have proposed to interpret in various ways: (1) as meaning ' a stone (slab) bearing a big sun,' to mark the point that tradition represents Buddha as a scion of the Solar Race of Ikshvāku; (2) as meaning 'a stone horse,' because Hiuen-tsiang says that the Aśoka pillar which he saw in the Lumbini garden was surmounted by the figure of a horse; (3) as meaning ' a flawless or faultless block of stone,' from which the pillar, which the text mentions immediately afterwards, was made. The suggestion seems also to have been made, that we might find here the equivalent of a Sanskrit * sila $v i n+$ gardabh $\bar{\imath}$, ' a stone she-ass.' But none of those proposals has received any substantial justification.

Dr. R. G. Bhandarkar, however, has expressed the opinion, but without going farther into the matter

1 And, in fact, in accordance with the general behaviour of ancient Indian kings. The inscriptions give us numerous instances of Vaishnava kings making or sanctioning grants to Saiva and other temples or priests, and vice, versâ. 
(JBBRAS, 20. 366, note 14), that "silāvigadabhīcha must be an enclosure or railing made of stone," and that "bhīcha is probably connected with bhitti or bhittika, "a wall.'"

That is the way in which I take the word $b h \bar{\imath} c h \bar{a}$. Just as we have in this same record $\bar{\alpha} g \bar{a} c h \alpha$ for $\vec{a} g a c h c h \alpha=$ agatya,- (and various other analogous forms might be cited), - so $b h \bar{v} c h \bar{a}$ stands for bhichch $\bar{a}=b h i t t i k \bar{\alpha}$ through such forms as *bhitti $\bar{a}$, *bhittiy $\bar{a},{ }^{*} b$ hity $\bar{a}$.

Before that, we might have vigada as representing vikata, 'having an unusual size or aspect,' in the sense of 'huge, large, great;' with the result 'a stone great wall.' But the natural expression for such a meaning as that would so obviously be mah $\bar{\alpha}-\operatorname{sil} \bar{\alpha}-b h \bar{\imath} c h \bar{\alpha}$ that such a possibility can hardly be admitted. Again, using vikata in another meaning which it appears to have, 'unusually handsome,' we might possibly say ' a stone ornate wall,' in the sense of something like a "Buddhist railing." But this, also, somehow does not seem satisfactory: and no traces of such a railing at Rummindēi have been reported.

The syllables which stand before $b h \bar{\imath} c h \bar{a}$ divide quite naturally into sila $+a v i+g a d a:$ and that is the way in which I take them. The Sabdakalpadruma cites Dandin as assigning to avi the meaning of prōehira, 'an enclosure, hedge, fence, wall;' and it cites the Sabdaratnavali as assigning to gada the meaning of vyavadhāna, 'covering; a cover, a screen.' It would, no doubt, be satisfactory if we could quote passages from texts, in which these two words, avi and gada, are actually found in those meanings. But we can hardly think that the Sabdakalpadruma, or the authorities cited by it, invented those meanings in order to enable us to explain the Rummindēi inscription. Accordingly, I do not hesitate to use those meanings, and to explain the whole expression as denoting 'a stone wall which is an enclosure and a screen,' or in other terms 'a stone surrounding and Downloaded from https://www.cambridge.org/core. INSEAD, on 22 May 2018 at 07:46:26, subject to the Cambridge Core terms of use, available at https://www.cambridge.org/core/terms. 
screening wall ;' exactly what would naturally be built round such a site as that with which we are concerned.

The remaining expressions which demand attention are two words in lines 4 and 5 which are plainly fiscal terms: the record says:- " the village Lummini was made ubalika and athabhāgiya." 1

On the understanding that in ubalike we have bali, ' tax, impost, royal revenue,' this term has been rendered as meaning 'exempt from assessment,' 'free of taxes,' 'revenue-free.'

The base ubalika would stand quite well, according to the inscriptional orthography of the period, for ubbalika as = to a Sanskrit *udbalika. Professor Buhler, however, pointed out that, on the analogy of uchchhrimkhala, ' unbridled, uncurbed,' 'unnidra, 'sleepless,' and other words, *udbali, as the basis of *udbalika, would have to be analysed into balēr=utkrānta or udgata, 'one who has gone up from, left, the taxes,' and that the use of it in the sense of 'exempt from taxes' would be unidiomatic. Accordingly, while rendering ubalike by "free of taxes," he thought that the word may perhaps be explained as ${ }^{*}$ avabalikah or *apabalikah; in support of which suggestion he cited Müller's Pāli Grammar, p. 42, as giving instances of a contraction of ava and apa to $u$.

It is certain that such a word as udbalika cannot be grammatically explained as meaning 'exempt from bali:' and the suggestion of apabalika or avabalika does not seem very satisfactory. In these circumstances, I treat this word otherwise. It is permissible to complete the ubalike

1 It may be observed that in gäme we might find the locative quite as much as the nominative, and so the text might mean :--_ at the village Lummini an ubalika was made, and an athabhägiya." It is, however, difficult to suggest any meanings for the two words in question from that point of view : moreover, we should then expect kālapite, ' was caused to be made,' rather than kate. 
of the text into umbalike, by supplying an Anusvāra. ${ }^{1}$ And, doing that, I venture to find here a vernacular word umbalika, 'free from rent,' which may be traced in Southern India in the Kanarese umbali, umbalige, ummali, etc., ' a rent-free grant,' as applied to either a plot of land or a village, and in the Telugu umbala, umbali, umbalike, and the Tamil umbalikkai, with more or less similar meanings. ${ }^{2}$

In athabhāgiye, the second component represents the Sanskrit bhägya, 'entitled to a share.' The first component is capable of representing either atha, attha, Prākrit forms of ashtan, 'eight,' or the attha which, alongside of attha, is a Prākrit form of artha, 'substance, wealth, property, etc.' On the view that it stands here for artha, the term athabhägiye has been rendered as meaning 'loaded with benefits,' 'a recipient of wealth,' and 'sharing in wealth, partaking of the king's bounty.' On the view that it stands for ashtan, the term has been rendered as meaning 'having eight plots (of the fiscal lands) granted to it,' and '(revenue-free) in its entirety;' the latter proposal being based on the curious assumption that, just as we now say "sixteen annas" to denote the whole of anything, "so "eight shares" may have been used in ancient times.

I find the explanation of this term in the Mannavadharmaśâstra, 7. 130, where it is said :- Pañchāśad-bhāga ādēyō rājñā paśu-hiraṇyayộ̣ dhānyānām=ashṭamō bhāgah shashṭ̂ō dvādaśa èva vā; "the king may take a fiftieth

1 In our text, the Anusvāra is shewn in bhayavam and lummini, but is omitted from dèvainampiyëna.

${ }^{2}$ It would appear that grammarians propose to derive $u m b a l i$ from $u n$, ' to eat, enjoy,' with bali in the sense of 'a gift, a present;' so that the primary meaning is 'an enjoyment-gift.' But we need not regard that proposal as conclusive; especially as it does not seem to account satisfactorily for the second component, except in the form bali, bali. More noteworthy is the use of the Drävidian ? in the Kanarese forms: instances can be cited, however, in which that letter has been substituted for a Sanskrit $l$. 
share of the cattle and gold; an eighth share, or a sixth, or indeed a twelfth, of the grains." I take it that in the time of Asóka the royal share in the grain in the district which included the village Lummini was oneeighth. ${ }^{1}$ And I gather that, while this royal share would ordinarily have been reserved in the case of such privileges as those which Aśōka conferred, even this right was relinquished in this instance, and the village Lummini was made absolutely and entirely rent-free as against the State.

Some remarks may be made regarding the various appellations of the king who is mentioned in this record.

His personal name according to literary works was Assóka or Asókavardhana. The latter form is found in the Vishnuu-Puranna, book 4, chapter 24, and in the Bhāgavata-Puranna, 12.1, 13: and the former of these works describes him as a son of Bindusāra son of the Maurya king Chandragupta. The shorter form, Aśōka, is found in the Vāyu-Purāna, part 2, chap. 37, verse 326, in the Dipavamsa and the Mahavaninsa, in the Samantapāsădikā of Buddhaghōsha, in the Divyāvadanna, and in the Jain Parisishțaparvan.

As is well known, his personal name has not yet been found in any records of his own time. And the earliest epigraphic mention of it is in the Junaggadh inseription of Rudradāman, containing a date falling in A.D. 150, which speaks of "the Maurya king Chandragupta" and "Aśóka the Maurya" (EI, 8. $46 \mathrm{f}$.).

In his edicts, as in the inscription which we have before us, the king is mentioned only by Prākrit forms of appellations which would in Sanskrịt be Dēvănāmpriya and Priyadarsin. But there is no question about his

1 It is hardly necessary to point out that, while ashtabhäga might mean ' eight shares,' i.e. ' eight per cent.,' it also means 'an eighth share ' just as freely : compare pañchāsad-bhaga in the verse quoted above, and shad-bhaga, 'a sixth share,' in, e.g., 8. 304, 305, 308. 
identity. The Dipavamsa uses the names Piyadassi, Piyadassana, Asōka, Asōkadhamma, and Dhammāsōka, just as may suit its verses, to denote one and the same person, whom it describes (6.15) as a grandson of Chandragutta and a son of Bindusāra. The same work, mentioning him as Piyadassana, tells us (6.1) that he was anointed to the sovereignty 218 years after the death of Buddha, and, mentioning him as Asōkadhamma, informs us (5. 101) that he reigned for 37 years. And the edict which we have at Sahasrām and other places (see page 495 below) gives for Dēvānampiya the date of 256 years after the death of Buddha, with details which carry back certain events in his career to almost the year, the twentyeighth after his anointment, in which DẽvānampiyaPiyadassi was still issuing his proclamations dated in that manner, and which further explain how it was that he was alive a year later than the time- (255 after the death of Buddha) - when his reign ended according to the Dipavamsa. Again, the statements of the Greek writers show that Chandragupta was a contemporary of Seleucus I., Nicator, of Syria (B.C. 312-280), and became king of Northern India at some time between B.C. 326 and 312 : and we do best, as I have intimated before now (this Journal, 1906. 985), if we take B.c. 320 as his initial year. The Dipavamsa, 5.100, assigns to Chandragupta a reign of 24 years. $^{1}$ It does not state the length of the reign of Bindusāra: but Buddhaghōsha and the Mahāvamsa (Turnour, p. 21, line 11) give 28 years; and the same period is deducible from statements made in the Dipavamisa, 11. 5, 12, 13, about king Mutasiva of Ceylon. There was then a period of four years (see this Journal, 1906. 985, note), during which Aśóka, having seized the sovereignty,

1 So also Buddhaghŏsha: see his Samantapāsādikā, in Oldenberg's Vinayapitaka, 3. 321, quoted in this Journal, 1906. 985, note. The Mahävamsa (Turnour, p. 21 , line 11) gives 34 years; but there can be no doubt that this is the result of some early copyist's mistake. 
was reigning without anointment. He was then anointed, $(24+28+4=) 56$ years after the initial date of Chandragupta; that is, in B.C. 264 (or 263). And, in perfect accordance with that, the thirteenth rock-edict of Dēvānampiya-Piyadassi mentions, as his contemporaries, Antiochus II., Theos, of Syria, Ptolemy Philadelphus of Egypt, Antigonus Gonatas of Macedonia, Magas of Cyrene, and Alexander II. of Epirus, whose dates fit in exactly with that reference to them.

There is, thus, no. doubt that the Asooka of literary works and the Junāgaḍh inscription is the DēvannampiyaPiyadassi of the edicts and the other inscriptions of that group, though the name Asooka is not found in them.

The fullest appellation of this king in his records is that which we have here in the Rummindēi inscription," the king Dēvănampiya-Piyadassi."

The full style, however, was not always employed: the following deviations occur :-

(1) With an omission, whether accidental or intentional, of the word meaning 'king,' we have "DēvannampiyaPiyadassi" in the opening clause of the Kālsi text of rock-edict 1 (EI, 2. 449); in the opening clause of the Shāhbāzgarhi text of rock-edict 2 (ibid.); and in lines 2 and 4 of the circular part of pillar-edict 7 (ibid., 270).

(2) We have "the king Piyadassi" in the inscriptions at the Barābar Hill caves (IA, 20. 364), and in the Bhabra or Second Bairāt edict (Cunningham, Inscriptions of A soka, CII, 1. plate 15).

(3) "The king Devannampiya" is found, quite exceptionally, in the opening clause of the Shäbhäzgarhi text of rock-edict 1 (EI, 2. 448).

(4) "Dệvānampiya" alone is found (a) in lines 14, 22, respectively, of the Dhauli and Jaugada texts of rockedict 10 (ASSI, 1. 121); (b) through the whole (as far as we can judge by the extant portions) of all the texts of rock-edict 13 after the opening clause, in which the full Downloaded from https://www.cambridge.org/core. INSEAD, on 22 May 2018 at 07:46:26, subject to the Cambridge Core terms of use, available at https://www.cambridge.org/core/terms. 
style is presented (EI, 2. $462 \mathrm{ff}$ ); (c) in the Dhauli and Jaugada separate edict 1 (ASSI, 1. 125, 127); $(d)$ in the opening clause of the Dhauli and Jaugada separate edict 2 (ibid., 127), and in lines $4,5,7$, and 8 of the Dhauli text of the same; $(e)$ in line 10 of the circular part of pillaredict 7 (EI, 2. 271); $(f)$ in the Queen's edict, and evidently in the Kōsambi edict (IA, 19. 125 f.); $(g)$ in both places (we can hardly doubt), in line 1 as well as line 6 , of the Sarnāth edict (EI, 8. 168) ; ${ }^{1}(h)$ in the Sahasrām, Rūpnāth, and Bairāt edict (IA, 22. 302); and (i) in the Brahmagiri, Siddāpura, and Jaṭinga-Rāmēśvara edicts (EI, $3.138 \mathrm{ff}$.).

In the appellation Piyadassi, = Priyadarsin, 'one who sees affectionately' or freely 'one who is of gracious mien,' there has been generally recognized a formal biruda or secondary name, almost, if not quite, amounting to a subsidiary personal name, and used by Asooka as his personal name for all practical purposes in the proclamations issued by him. ${ }^{2}$ And this appellation has been customarily treated without translation.

1 The restoration of the full style from simply the extant syllables dêva in line 1 can hardly be admitted against the use of simply "Dēvānampiya" in line 6 and in the face of so many other indications to the contrary. It may also be remarked that it is by no means certain that the syllables pāta in line $\mathbf{3}$ may be restored into Pătaliputé.

2 This appellation appears to be found elsewhere, either in Sanskrit or in Pāli, only in the cases of a Therra (Dipavanisa, 19. 5) and one of the previous Buddhas (Nidānakathā, $38 \mathrm{f}$.; Mahāvamina, 2).

The other form, Piyadassana, presented by the Dipavamisa, is not found in the inscriptions of Asōka, and seems to have been used in the Ceylonese work simply for metrical conveniences. It has not the same purport ; its meaning being 'dear or grateful to the sight.' It is found elsewhere as an ordinary epithet. In one of the Nāsik inscriptions (ASWI, 4. 108, No. 18 ; EI, 8. 60 ; line 3-4) king Gōtamīputta-Siri-Sạtakanni is described as patipuna-chada-madala-sasirika-piya-dasana, "lovely and grateful to the sight like the orb of the full moon." The epithet is applied to Sită in the Rāmāyaṇa (Gorresio), 5, \$24, 1, and is probably of frequent occurrence in literature. As a proper name, it is presented in the case of a mythical Chakravartin by the Mahāvastu, ed. Senart, 1. 114 , line 12. 
The appellation Dēvānampiya, = Dēvānāmpriya, 'dear to the gods,' has been treated differently, as an epithet. ${ }^{1}$ Prinsep started with a preference for using it without translation:- "Thus spake king Devánampiya Piyadasi" (JASB, 6, 1837. 581-4, 590, 596-9, 603-8). Almost directly, however, he introduced translations,- " king Piyadasi, beloved of the gods" (ibid., 585; 7, 1838. 257, 259), and "the heaven-beloved king Piyadasi" (ibid., 7, 1838. 249-56, 258, 259, 262). And the practice has been continued, of translating it by "Beloved of the gods." 2

Now, the enjoyment of the appellation Dēvānampiya was not confined to Aśoka. In the first place, the text in the Nāgăxjunī Hill cave inscriptions (IA, 20. 364 f.) :Dashalathēnā Dēvānampiyēnā ānamtaliyam abhishitēnā, is interpreted as meaning "by Dashalatha-Dēvānampiya, as soon as he was anointed," and as assigning the appellation to Dashalatha, = Daśaratha, who according to the VishṇuPurāna was a grandson of Aśōka. That, however, is open to question : the appellation Dēvannampiya elsewhere always stands before any other name which it qualifies; and this point, coupled with the free use of the appellation

1 The curious later use of this word in the sense of 'dull, stupid, silly, simple, foolish,' is well known : Hēmachandra in his Abhidhänachintāmani, verse $35 \overline{3}$, gives it as synonymous with mülha, mürkha, and similar words. The idea underlying that seems to be a fairly universal one; that people of weak intellect are under the special protection of heaven.

The promiscuous use of the Jain variant dévänuppiya is well illustrated in the Antagada-Dasāo, which I quote from Dr. Barnett's appreciative translation in our Oriental Translation Fund Series. The epithet is there applied to kings, of course, and to queens and princes ; but also to chamberlains (19), to "the readers of tokens of dreams" (23), to cityfolk in general (36), to a prince's waiting-man (37), to a saint (38), to a king's barber (45), to friars (65), and even to the members of a gang of hooligans (87).

2 Except that Mr. Vincent Smith would regard Dēvānaminiya as "a mere formal title of kings" and Piyadassi as " a mere epithet or title," and would substitute for both "His Sacred and Gracious Majesty" (IA, 1905. 4), which words do not preserve any reminiscence of the original terms. 
by itself to denote Aśōka (see page 482-3 above), suggests that we should perhaps here translate "by Dashalatha, as soon as he was anointed by Dēvānampiya (i.e. Aśōka),"such anointment having been made in circumstances indicated on page 497 below. But, however that may be, the Dipavamsa shews (11. 25) that the appellation belonged also to Asōka's contemporary, DēvānampiyaTissa of Ceylon, and often (e.g., 11. 14, 19, 20, 29, 30, 39) uses it alone to denote that king. And an inscription from Ceylon shews (Epi. Zeylanica, 1.60 f.) that, among other kings there, it belonged to Vankanāsika-Tissa, Gajabāhuka-Gāmini, and Mahallaka-Nāga.

Further, this appellation seems to have been to a certain extent interchangeable with the word rajjan, läjan, 'king.' In rock-edict 8 , where the Kālsĩ, Shāhbāzgarhī, and Mansehra texts say:- "In times gone by, the Dēvānampiyas went forth on pleasure-tours," the Girnār text (see page 488 below) and the Dhauli and Jaugada texts (ASSI, 1. 199) present rāj $\bar{a} n o$, läjāne:- "In times gone by, the kings went forth," etc.: which suggests that the appellation belonged at least to Chandragupta and Bindusāra, if not to also other kings before them. And five times, in lines $5,6,10,11$, in the Jaugada text of the separate edict 2 , lajjan is presented against the dēe $\bar{\alpha}-$ nampiya of the Dhauli text (op. cit., 128).

At the same time, the extent to which this appellation was used above to denote Aśōka marks it as more than a mere epithet in his case. It has been customary to use the appellation without translation in the case of Dēvānampiya-Tissa of Ceylon. And it seems appropriate to adopt the course which suggested itself at first to Prinsep, and to use the appellation without translation in the case of Asóka also.

With this introduction, I give my translation of the Rummindēi inscription as follows; substituting the Downloaded from https://www.cambridge.org/core. INSEAD, on 22 May 2018 at 07:46:26, subject to the Cambridge Core tertns.oflis's, available at https://www.cambridge.org/core/terms. 32 
nominative for the instrumental construction of the original :--

\section{Translation.}

The king Dẽvānampiya-Piyadassi, when he was twentyyears-anointed, did (this place) the honour of coming (here) in person. Because Buddha was born here, the Sakya saint, ${ }^{1}$ he caused a stone surrounding and screening wall to be made, and a stone pillar to be set up. Because the Blessed One was born here, he made the village Lummini free of rent and entitled to the (king's) eighth share (of the grain).

\section{The conversion of Aśōka to Buddhism.}

In connexion with a remark made on page 475 above in discussing the meaning of mahizyite, and for some other purposes, we must now determine the stage in Aśoka's career at which he became converted to Buddhism.

The Dippavamisa makes it clear (6. 18) that Buddhism was not his original creed, but leaves the matter otherwise doubtful. The Mahāvamisa, however (Turnour, 23, line 3), ${ }^{2}$ describes him as starting by favouring the Brāhmaṇs,

1. The question of the extent to which we must or may restore or complete forms which are presented more or less imperfectly in original texts in consequence of peculiarities of spelling, is liable to be somewhat complex. In the present case, we must certainly write "Buddha" for the "Budha" of the original, and supply the omitted. Anusvāra of "Dēvānampiya;" and it is proper to write "Piyadassi" with the double ss. But there is neither necessity nor authority for substituting, as previous translators of this record have done, "Sakkya" for the "Sakya" of the original : the latter form is well substantiated by the Mahāparinibbanna-Sutta, the Vinayapitaka, and other early texts ; and there is no evidence in support of the form "Śäkya" until very much later times. On the general question of this tribal name, see my remarks in this Journal, 1905. $645 \mathrm{ff}$; 1906. $161 \mathrm{ff}$.

2 Compare Buddhaghōsha in his Samantapāsādikā; see the Vinayapițaka, ed. Oldenberg, 3. 301. 
as his father had done. This latter work also states (28, line $4 \mathrm{ff}$.) ${ }^{1}$ that the Therras of the Second Council, which was held 100 years after the death of Buddha, foresaw that 118 years later,- that is, at the time when Aśoka was to be anointed to the sovereignty,- a calamity would befall the faith, to remove which it was arranged that the great priest Moggaliputta-Tissa should be born: and this seems to suggest that Aśoka was at first actively hostile to the Buddhists. The Dipavamsa and the Mahãvamsa both appear to place the conversion of Asōka to Buddhism in the fourth year after his anointment to the sovereignty. But his records shew that any such statement as that is not correct.

The fourteen rock-edicts of Asooka were framed and published in and after the thirteenth and fourteenth years after his anointment. Edicts 1 and 2, indeed, do not contain dates, and may possibly have been framed somewhat earlier. $^{2}$ But edict 3 says (EI, 2. 450, Girnār text):Dbādasa-väs-ābhisitēna mayā idam āñapitam; "by me, twelve-years-anointed, this command has been issued." 3 In the same way, edict 4 concludes with the statement :"By the king Dẽvānampiya-Piyadassi, twelve-yearsanointed, this has been caused to be written." And in edict 5 the king says :- "By me, thirteen-years-anointed, Dhammamahāmätas (High Ministers for dhamma) have been created."

' Compare, again, Buddhaghōsha ; loc. cit., $294 \mathrm{f}$.

2 It has, however, been inferred from pillar-edict 6 that no edicts were issued before the thirteenth year.

3 This and similar passages in the edicts of both series have sometimes been translated as if the records were subsequent ones, registering past events: for instance, the above words have been rendered thus (EI, 2. 466) :- "When I had been anointed twelve years, this following order was given by me." But the edicts were certainly framed and actually issued by proclamation, as synchronous records of current acts, before being brought together on the rocks and pillars; and the dates are better translated accordingly. 
The remaining rock-edicts are not dated. But two of them mention events of earlier date, and present important statements in connexion with them.

The 13th edict commences by reciting that the king conquered the Kalinga countries when he was eight years anointed, and goes on to say that, from the time when those territories were annexed, the king had zealously protected dhamma, had felt love for dhamma, and had inculcated dhamma. And that recital, and the words which follow it, including a declaration that "Dēvänampiya holds the conquest by dhamma to be the chief of all conquests," make clear the point that the king's thoughts were first led into the direction of dhamma by the miseries that attended the war by which Kalinga was added to the empire. ${ }^{1}$

The 8 th edict contains something which is regarded as still more noticeable : it commences by reciting (EI, $2.456 \mathrm{f}$., Girnār text):-- Atikātam amiaram rājāno vihära-yätäm ñayāsu ${ }^{2}$ eta magayvā añāni cha ètārisāni abhiramakāni ahưnsu so Dēvānampiyo Piyadasi rājā dasa-vassābhisito sainto ayāya sambōdhim tēn =ēsā dharnma-yātā; " in times gone by, the kings went forth on pleasure-tours, on which there were hunting and other similar amusements: this king Dèvānampiya-Piyadassi, when he was ten-yearsanointed, went to sambodhi; therefore (there is now) this touring for dhamma."

There have been various discussions of this passage, based principally on the use in it of the term sambodhi, 'proper, true, or perfect knowledge, understanding, enlightenment;' with at least one plain expression of

1 Those miseries are indicated in the edict: " 150,000 living beings were carried away (as captives) ; 100,000 were slain ; and many times as many died ;" etc.

2 It seems hardly necessary to treat this word as an irregular spelling of niyyäsu. The $\tilde{n}$ implies an original $n y$ : Childers gives $n \bar{y} y \bar{a}$, as well as niyy $\bar{\alpha}$, as = niry $\bar{a}$, ' to go forth :' and from $n \bar{\imath} y \bar{\alpha}$ we might surely have nyayãsu, which would become ñayāsu. 
opinion that the two edicts, taken together, shew that Asóka felt a preliminary call to Buddhism in the ninth year after his anointment to the sovereignty, and was definitely converted to that faith in the eleventh year.

Now, a similar and practically identical word, sambödha, with exactly the same sense, is found, not only in Buddhist literature, ${ }^{1}$ but also elsewhere: in the Mahābhārata, 3. $§ 312,17,375$ we are told:-Jñānam tattvārtha-sambōdhah ; "knowledge is the proper understanding of true meaning:" again, in the same work, 12. $§ 17,531$, we have :- Ajñātānām cha vijñānāt=samimbōdhād = buddhir = uchyatē ; " wisdom is so called (as resulting) from a knowledge and proper understanding of things not (generally) known." But it may be urged that we have here, not sambodha, but sambödhi; that the latter form is (or seems to be) confined to Buddhist literature, in which we have also the appellation Sambuddha as synonymous with the name Buddha itself; and that in that literature it denotes (see this Journal, 1898,620 ) "the insight of the higher stages of the path to Arahatship." Further, stress may be laid on the point that, in the place of the ayāya of the Girnār text, all the other versions ${ }^{2}$ present forms from the verb nikkham, = nishkram, which suggests the idea of the technical Buddhist nitkhamana, nishkramana, "the going forth from the house-life to the houseless state of asceticism and wandering mendicancy.' But any force which the latter argument might have is at least reduced by the fact that, instead of the ñayasu of the Girnār text, all the other versions present there again, in connexion with even the pleasure-tours, forms from the verb nikkham.

1 For instance, in the Vinayapitaka, Mahãvagga, 1. 6, 17, 18.

I With the qualification, which applies also just below, that the word is illegible in the Jaugada text. 
It is not known when the 8 th rock-edict was framed; except that it was not framed earlier than the fourteenth year after the anointment of Aśoka to the soverejgnty. It may be taken that each set of the whole series of the rockedicts was incised all at once, and not in instalments. But it does not follow that edicts 6 to 14 were framed in the fourteenth year along with edict 5 , and that the whole series was published in a collective form in that year; and it seems improbable that that was the case. We know from the seventh pillar-edict that Asokka was still issuing his formal proclamations up to at any rate the twenty-eighth year. And it is quite possible that the 8th rock-edict was framed even later than that, and at a time when, having really become a declared Buddhist, Asóka might not unnaturally introduce a technically not quite correct term in referring to a previous stage in his career. But all that we need really understand from the reference to sambo $d h i$ in the 8th rock-edict is that Aśoka. had then, in the eleventh year, realized fully the propriety of attending to dhamma.

This much at any rate is certain, whatever may be doubtful; namely, that Aśōka did not renounce the houselife and take up the life of asceticism and wandering mendicancy at the time specified in the 8th rock-edict, viz. the eleventh year after his anointment. What he did do then was to substitute tours of dhamma for pleasure-tours. And the edict goes on to explain the nature of the said tours of dhamma; it says:- "On these tours this is what takes place: the interviewing of Bāmhanas (Brāhmaṇs) and Samañas, and the giving of gifts to them; the interviewing of Elders, and the distribution of gold to them; the interviewing of the people of the country-side; the inculcation of dhamma; and the making of inquiries about dhamma."

The question remains:- What was the dhamma for which these tours were instituted, and which forms so 
constant a topic of all the edicts? The answer is given by an exact definition of dhamma in the second pillar edict, which was framed, as we gather from the dates in the first and fourth edicts of that series, in the twenty-seventh year after the anointment of Aśoka: we are there told (EI, 2. 249):-Dēvānampiye Piyadasi lāja hēvam āha dhamme sādhu kiyam chu dhammē=ti ap-āsinave bahukayāne dayā dāne sache sōchayē=ti; " thus saith the king Dēvänampiya-Piyadassi: 'dhamma is good: but it will be said, to what does dhamma amount?: the answer is, little addition to evil passions, ${ }^{1}$ many beneficial deeds, compassion, charity, truthfulness, and purity."

This definition is plain and instructive. And a perusal of the rock and pillar edicts makes it clear that it governs, throughout, the dhamma which is inculcated and provided for by them. That dhamma is not in any way the Buddhist Dhamma, the Faith ; and the term is not properly rendered by "the Religion," "the Sacred Law," or any such expression. It is the ordinary dharma of kings, which is laid down in the Mānavadharmaśästra, 1. 114, as one of the topics of that work. ${ }^{2}$ In the rock and pillar

1 The word apassinave is difficult. One component of it, äsinava, occurs again twice in pillar-edict 3. M. Senart has explained it as $=\bar{a} s r a v a$, through such forms as *äsirava, *äsilava (Inscrs. de Piyadasi, 2. 13). And the Pãli equivalent, ăsava, is given by Childers as meaning 'human passion, sin, corruption, depravity.'

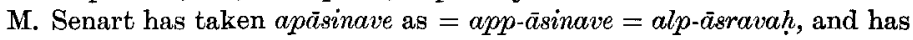
rendered the term by "le moins de mal possible" (op. cit., 2. 15). Professor Bühler took it as = apāsravam (with apa as the first component) in the sense of apasravatvam, and rendered it by "sinlessness" (EI, 2. 249).

The bahu in bahu-kayāne seems to point clearly to apa standing for appa $=a l p a$. And asinava, whatever may be its etymology, is explained in the second passage in the third pillar-edict, where we are told (EI, 2. $250 \mathrm{f}$.) :-Imāni āsinava-gāmīni nāmā = ti atha chamdịye nithūliye kōdhe māne isya ; " these things verily constitute äsinava; namely, hot temper, harshness, anger, pride, envy."

2 Rajjnas = cha dharmam = akhilam; "and the whole duty of a king:" this is Professor Bühler's rendering, The Laws of Manu, SBE, 25. 28. 
edicts, Buddha is not mentioned at all, and the Samgha only once, in a passage in the latest of the pillar-edicts (see the next paragraph) which simply places it on a par with all the other creeds. The twelfth rock-edict is an express declaration of Aśōka's desire to treat all beliefs with impartial toleration and encouragement. And the distinct object of both the rock and the pillar edicts was, not to propagate Buddhism or any other particular religion, but to proclaim the determination of Asóka to govern his realm righteously and kindly in accordance with the duty of pious kings, and with considerateness for all forms of religious belief, and to acquaint his subjects with certain measures which he had taken to that end, and to explain to them how they might co-operate with him.

We shall come directly to the proclamations issued by Aśōka as a Buddhist. We must first notice a declaration made by him as to the duties of the Dhammahämätas, the High Ministers for dhamma, the appointment of whom was made in the fourteenth year after his anointment, as recorded in the fifth rock-edict. A general description of their functions is given in that edict (EI, 2. $467 \mathrm{f}$.), and commences with the statement that they were concerned with all the sects. This statement is amplified in the circular part of the seventh pillar-edict, framed in the twenty-eighth year: Asōka there says (EI, 2. 270, line 4 f.) :- " My Dhammamahāmātas are oceupied with various affairs of a beneficent nature : they are occupied with all the creeds, both of wandering ascetics and of those who are living the house-life: they were appointed by me in order that they should be occupied with the affairs of the Samgha, and so also with Bābhanas (Brāhmaṇs), Ājīvikas, Niggaṇthas (Jains), and (all) the different creeds: the. various Mahämātas (are occupied) with various specific (affairs): but my Dhammamahāmätas are occupied with these (just mentioned) and all the other creeds." We have here the only reference to the 
Buddhist Samgha that is to be found in the rock and pillar edicts: ${ }^{1}$ and, as has been said, Buddha is not mentioned in them at all. The Samgha is mentioned here on equal terms with Brāhmaṇs, Jains, etc. And we can plainly see that, in the twenty-eighth year after his anointment, Asooka was still treating all the religious sects with the impartial toleration and encouragement which is the express topic of the twelfth rock-edict (EI, 2. 470), and that, even if he had then begun to feel any leaning towards the Buddhists, he had at least not identified his interests with theirs. We are, indeed, sometimes told that Asōka convened the Third Buddhist Council in the seventeenth or eighteenth year after his anointment, and then despatched missionaries to propagate the faith in the border-countries. But there is nothing in that assertion. In the records of Asooka, there is no mention of the Council; and it is at least difficult to find fairly any allusion to missions of the kind described in the books. And neither by the Dipavamsa, nor by Buddhaghōsha, nor by the Mahāvamsa, are the occurrences in question attributed to him. The three authorities agree that it was Moggaliputta-Tissa who convened the Council and sent out the missionaries. Aśōka is not mentioned by them in connexion with the missions at all. In respect of the Council, the Mahāvamsa fills out a verse by saying (Turnour, 42, line 12) that it was held rakkhāy= $\bar{A} s \bar{o} k \alpha$ räjino, " under the protection of king Asōka;" but, beyond that, Aśoka is mentioned in connexion with it merely by way of stating the date of it.

1 It is assumed that the reference here really is to the Buddhist Samgha. But the word samgha may denote any community whatsoever, and is explained by Mēdhātithi under Mānavadharmaśăstra, 8. 219, as meaning 'communities and corporations of merchants, mendicants or monks, Chaturvèdins, and so forth' (SBE, 25. 293, note). The term in the text of the seventh pillar-edict, samghathasi, might be taken as meaning "the affairs of (all recognized) communities." 
The only records of Aśōka which are Buddhist records and mark him as a Buddhist are the following:-

(1) The Bhabra or Second Bairāt edict: Inscriptions de Piyadasi, 2. 198; IA, 20. 165. In this, the king, addressing the Mãgadha Samgha, the Buddhist Community in Magadha, says :-- "Ye know, Sirs!, how great are my reverence and favour towards Buddha, the Dhamma, and the Samgha: everything, Sirs!, that was said by the Blessed Buddha was truly well said: and so far indeed, Sirs !, as I myself ean foresee, I ought to feel confident (? $)^{1}$ that the true religion will thus endure for a long time." And the edict goes on to mention by name certain Buddhist texts which the king commends to the Bhikkhus and Bhikkhunis, the monks and nuns, for constant study by them. This record is not dated : but it is plainly of later date than the seventh pillar-edict framed in the twentyeighth year, and is certainly to be referred, along with Nos. 2, 3, and 4, to some time in the period of six years which is mentioned in No. 5 below.

(2) The Sārnāth edict: EI, 8. 168; and see JASB, 1907. No. 1. 1. Amongst other things, this prescribes, in line $4 \mathrm{f}$., a penalty to which Bhikkhus and Bhikkhunis were to be subjected if they should break the rules of the Samgha: and a passage in line $9 \mathrm{f}$. connects it closely with No. 5 below. If this record was dated, the date was in lines 1 and 2 , and has been lost.

(3) The Sāñchi edict: EI, 2. 87, 367. This is very fragmentary : the extant remnant of it, however, mostly

1 Cunningham's lithograph in Inscriptions of Asoka, CII, 1. plate 15, shews tavitave: and the alteration of that into tam vatave does not seem either necessary or satisfactory. I take the word as tavitave $=$ tavitum, tôtum, the infinitive of $t u$, 'to have authority, be strong.' Or we might perhaps take it as = stavitum, stotum,- "I ought to give praise," - with an exceptional change of $s t$ to $t, t$, instead of $t h, t h$.

In the preceding clause we seem to have disēyam as =drišéyam, the Vèdic potential of $d r i s$, ' to see.' 
coincides with line $4 \mathrm{f}$. of No. 2. Here, again, the date, if any was recorded, is lost.

(4) The Kōsambì edict: IA, 19. 126. This, also, is very fragmentary : but here, again, the extant portion mostly coincides with line $4 \mathrm{f}$. of No. 2 . It seems not to have been dated.

(5) The edict which we have at Sahasräm, Rūpnāth, and Bairāt in Northern India (Inscrs. de Piyadasi, 2. 166 ; IA, 20. $155 ; 22.302$ ), and at Brahmagiri, Siddāpura, and Jaṭinga-Rāmēŝvara in Mysore (JA, 1892, 1. 486 ; EI, 3. 138). ${ }^{1}$ This record is a lecture on the good results of displaying energy in matters of religion. It is dated 256 years after the death of Buddha, ${ }^{2}$ inasmuch as it quotes a short sermon which, it says, was delivered 256 years previously by the Vivutha, Vyutha, or Vyūtha, i.e. Buddha. ${ }^{3}$

This last record is, by reason of its date, perhaps the most important of all the records of Aśōka. The Dipavamisa tells us (6. 1) that Aśōka was anointed to the sovereignty 218 years after the death of Buddha, and (5. 101) that he reigned for 37 years (from the time of his anointment). We thus see that this edict was framed $(256-218=) 38$ years after his anointment, and one year, more or less, after the end of his reign. This last detail seems at first sight somewhat puzzling. But the

I For the Mysore texts, see also Epigraphia Carnatica, 11. Mk. 14, 21, 34 , and plates.

2 The meaning, of course, is 'at some time in the 257 th year current, when 256 years had been completed.'

3 As regards some remarks by Professor Norman on page $13 \mathrm{f}$. above, I think I have made it clear (see this Journal, 1907. 521, and note 2) that I am prepared to concede that my proposal to render the appellation Vivutha, etc., by "the Wanderer" is not to be regarded as final : the meaning which we must assign to lakkhapetavaya indicates that we must find for vivasetavayya, and so perhaps for Vivutha, etc., some meaning which is not connected with the idea of 'wandering forth.' But the points will remain, that the appellation denotes Buddha, and that the 256 years mean the period elapsed since his death. 
Brahmagiri text, which is the clearest version, discloses the explanation." There was a period of "somewhat more than two and a half years," during which Aśōka was a Sāvaka or an Upāsaka, a Buddhist disciple or layworshipper," without much exerting himself. That was followed by a period of "somewhat more than six years," including a specially signalized period of one year, during which Aśoka, having joined the Samgha, did exert himself strenuously; with the result (we are told) that the gods of Jambudvipa (India) with their followers were proved to be false,- and (it follows) the doctrine of Buddha was established as the true religion. Further, the Mysore versions differ from those of Northern India in presenting a preamble, which tells us that the edict was issued from a place named Suvannagiri, and that it was communicated to the Mahāmātas, the High Ministers, at Isila in Mysore, not directly by Aśoka himself, but through the Ayaputa, i.e. the Prince, and the Mahāmātas, who were in charge of the district which included Suvannagiri. We have, further, the well-known statement of I-tsing, mentioning an image of Aśoka dressed as a Buddhist monk. ${ }^{3} \quad$ And, putting all these details together, we see that the facts were as follows:

Aśōka was converted to Buddhism and became a disciple or lay-worshipper about half-way through the 30th year

1 I still hope to find leisure, some day, to demonstrate this matter by a critical comparison of the texts. Meanwhile, I think that anyone, able to read the originals, who will examine them in the light of what I say, will readily see that the facts were as I state them.

2 The word in the Rūpnäth text is perhaps sävake: in the Sahasrām, Bairāt, and Śiddäpura texts, it is upāsake. In the Jatinga-Rämēśvara text, this part of the record is hopelessly illegible. In the Brahmagiri text, while all the rest is remarkably clear, this word cannot be decided. either way ; owing apparently to some exceptional hardness of the rock at this point, it seems to have been left unincised, or almost so: but the preference is in favour of upassake.

3 Takakusu, Records of the Buddhist Religion, 73. 
after his anointment to the sovereignty. ${ }^{1}$ A little more than $2 \frac{1}{2}$ years later, and consequently soon after the commencement of the 33rd year, he formally joined the Buddhist Samgha. A little more than 5 years after that, early in the 38th year,- when he had completed 37 years and something over, ${ }^{2}-$ he followed a not infrequent custom of ancient Indian rulers, and abdicated, and, taking the vows of a monk, withdrew to spend his remaining days in religious retirement; perhaps (see page 485 above) installing Dasaratha as his successor, and anointing him with his own hand. And from that retirement, one year later, early in the 39th year, he sent forth this notification, proclaiming Buddhism as the true and established religion. In Northern India, which had formed his own dominions, he was still able to issue the edict without any intermediaries. But, in communicating it to a foreign power in Mysore, where quite possibly he was personally unknown, he had to send it through the channel of the officials of the district in which he was living in retirement. And to that necessity

${ }^{1}$ So also, practically, Professor Bühler, basing the result on his later and mature consideration of the Sahasrām, Rūpnāth, and Bairāt texts : "his conversion falls about the twenty-ninth year of his reign" (IA. 22. 302 ; compare EI, 3. 138). Originally, guided by the Mahāvamisa, he had placed it in the fourth year (IA, 6. 153a).

Professor Kern, treating the expression $d \bar{a} y \bar{a} d \bar{o}$ säsanē in the Dippavamisa, 7. $13 \mathrm{ff}$, as meaning that Aśoka was still, in the seventh year, only a "pretender" to the Faith, but holding it to be not improbable that he had become a convert in the twenty-eighth year when the seventh pillar-edict was issued, has nevertheless expressed the opinion that the Sahasrām, etc., edict must be placed after the latter date, because it stamps Aśōka as a decided Buddhist zealot (Manual of Buddhism, 114, and note 3 ).

It has been shewn above that the Sahasrām, etc., edict was framed $256-218=38$ years after the anointment of Aśoka. On the other side we have $29 \frac{1}{2}+2 \frac{1}{2}+6=38$, with an indefinite but small "somewhat more" to be added in connexion with the $2 \frac{1}{2}$ and the 6 .

2 The statement of the Dipavamisa, that he reigned for thirty-seven years (from the date of his anointment), of course does not mean thirtyseven years exactly to the day; but it does mean that he had completed thirty-seven years. 
we owe the interesting result that we can point, not merely to the locality, but perhaps to the actual abode in which Assoka spent his closing days: we may find it in a cave-temple, measuring (see IA, 1902. 71) forty feet by fifteen, and containing in 1820 a Jain image and a stone couch, and occupied then by a Bairāgi, which exists in Suvarṇagiri, Sōnagiri, Sōngir, one of the hills surrounding the site of the ancient city Girivraja in Magadha, Behar. 